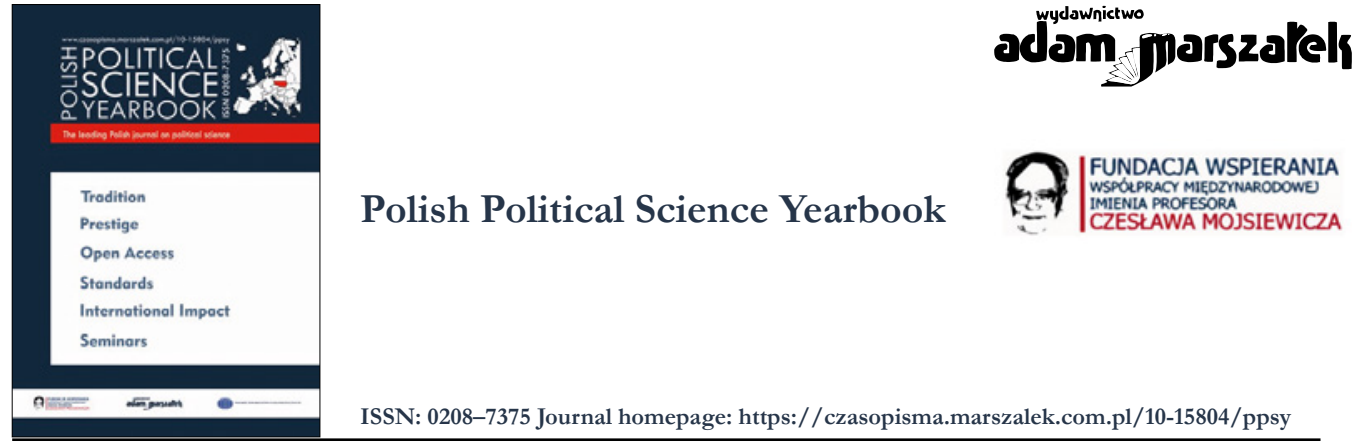

\title{
Book Review: Janusz Mariański, Socjologia i moralność. Czym jest i dokąd zmierza socjologia moralności? [Sociology and Morality. What Is the Sociology of Morality and Where Is it Heading?], Adam Marszałek Publishing House, Toruń 2019, pp. 355.
}

\section{Mariusz Zemło}

ORCID: 0000-0003-0945-8651

To cite this article please include the following information:

- Journal title: Polish Political Science Yearbook

- Volume number: 50

- Year of publication: 2021

- Published ahead-of-print

Example styles:

[APA Style]: Zemło, M. (2021). Book Review: Janusz Mariański, Socjologia i moralność. Czym jest i dokąd zmierza socjologia moralności? [Sociology and Morality. What Is the Sociology of Morality and Where Is it Heading?], Adam Marszałek Publishing House, Torun 2019, pp. 355. Polish Political Science Yearbook, 50(issue number), pages. https://doi.org/10.15804/ppsy202136

[Chicago Style]: Mariusz Zemło, “Book Review: Janusz Mariański, Socjologia i moralność. Czym jest i dokąd zmierza socjologia moralności? [Sociology and Morality. What Is the Sociology of Morality and Where Is it Heading?], Adam Marszałek Publishing House, Torun 2019, pp. 355." Polish Political Science Yearbook 50, no. [issue number] (2021).

To link to this article: https://doi.org/10.15804/ppsy202136

Published ahead-of-print

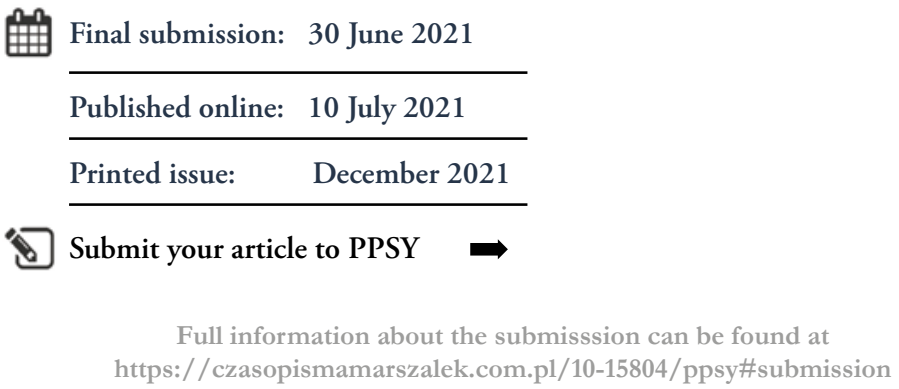




\section{Mariusz Zemło}

University of Białystok (Poland)

ORCID: 0000-0003-0945-8651

e-mail: zemlo@uwb.edu.pl

Book Review: Janusz Mariański, Socjologia i moralność. Czym jest i dokąd zmierza socjologia moralności? [Sociology and Morality. What Is the Sociology of Morality and Where Is it Heading?], Adam Marszałek Publishing House, Toruń 2019 , pp. 355.

Sociological reflection on morality has a long tradition. It goes back almost to the beginnings of the "liberation" of social thought from philosophical wings. Already the classics of sociology believed that moral issues are among the most important in social phenomena and processes. A little later, over a decade since that moment, the followers of Émile Durkheim and Max Weber attempted to put moral issues into an unambiguous formal framework. In this way, they wanted to legitimize their respective research area and codify the actions undertaken by scientists into a fully-fledged sociological discipline to improve the empirical activities undertaken within it. One of the first researchers to undertake this task was Maria Ossowska. She realized these intentions in two monumental works: Podstawy nauk o moralności [Fundamentals of the Sciences on Morality] (1947) and Socjologia moralności [Sociology of Morality] (1963).

Also, at the end of the 1980s, more than a quarter of a century after Ossowska's Socjologii moralności, Janusz Mariański undertook to write an author's synthesis on the sociology of morality. The first attempt to do so was presented in his publication Wprowadzenie do socjologii moralności [Introduction to the Sociology of Morality] (1989), the second is Socjologii moralności [Moral Sociology] (2006). The newer work by the head of the Department of Sociology of Morality at the Catholic University of Lublin refers to the former concerning the character and arrangement of the issues raised. However, it elaborates some of the topics from the first book, only mentioned there, and adds new issues, considering the current 
achievements of science. After these endeavors, science was enriched with over 500 pages that comprehensively and coherently present the sociology of morality.

It covers, among others, the following issues: developing the conceptual apparatus of the discipline, clearly indicating and discussing the research areas of the discipline, defining the place of the sociology of morality among other sciences on morality, describing the social determinants of morality, and presenting the typology of morality. It seemed that the book fulfilled the tasks set before it in an entirely satisfactory way. However, it turned out that such an assumption was not entirely correct because, after almost 15 years, we have another attempt to organize and present the sub-discipline dealing with morality. Once again, this happened thanks to Janusz Mariański, as evidenced in the dissertation Socjologia i moralność. Czym jest $i$ dokad zmierza socjologia moralności? [Sociology and Morality. What Is the Sociology of Morality and Where Is it Heading?] published in 2019.

The work consists of five chapters. In the first chapter, the author discusses the more important theoretical positions. They are conventionally divided into the "old" and the "new". In the first group, the presentation takes into account the views of Emil Durkheim, Eugen Dupreel, Talcott Parsons, Niklas Luhmann, Thomas Luckmann, and Maria Ossowska. In relation to the "new" positions, he assigns and discusses the achievements of Patrick Pharo, Horst Jürgen Helle, Józef Majka, Anna Pawełczyńska, Adam Podgórecki, Władysław Piwowarski and personalistic trends. In presenting the history of thought focused on morality, the author intended to recreate the basic ideas of individual sociologists and emphasize the importance of the contextual embedding of these ideas, mainly institutional and social. Moreover, this type of historical chapter, in the mind of Janusz Marianski, was of fundamental importance from the point of view of more general conclusions concerning the assessment of the dominant paradigms present in the research on morality, such as indicating the direction of possibly practicing the sociology of morality in the $21^{\text {st }}$ and other centuries, which found a place in the further chapters of the book.

Already in the second chapter of the publication, the author aims to describe the sociology of morality. Here, after Lexikon der christlichen Moral [Lexicon of Christian Morals] (1976), he presents it by focusing on: a) moral awareness, b) moral behavior, c) values and norms functioning in society, and d) comparative studies of the moral life of various communities. The discussion in this chapter also includes issues of the conceptual accuracy of the basic categories present in the literature on the subject and models of morality research. While discussing the last issue, the following were considered: the empirical-statistical, normative-institutional and autonomous model, otherwise called individualized. After these fundamental findings, the time has come to define the identity of the sub-discipline in question. This issue closes the second chapter.

The third chapter is devoted to human dignity. Though the chapter title is "human dignity", it is not discussed in general, but from the point of view of the proper orientation point on the study of morality. In this way, the author wanted to propose a new paradigm 
that could be applied in the sociology of morality. The attempt made seems completely convincing and is worth promoting further.

In the fourth chapter, Janusz Mariański discusses two basic elements of the moral order: values and norms. Apart from presenting basic information that clarifies the fundamental issues concerning these, he also focuses on the condition of these morality parameters in the contemporary world.

The book ends with chapter five that emphasizes the need to undertake educational activities aimed at strengthening values that can constitute a reference point for most people against the background of assessing the moral condition of contemporary society (including Poland), especially concerning the crisis of contemporary society universal values. The pages of this chapter show the concern of a social researcher with many years of experience on the condition of society. He is well aware that the moral dimension is fundamental from the point of view of this condition.

In this book, the reader receives various material in terms of the nature of its content. This content consists of: a) theoretical material organizing the space of the presence of moral facts, b) empirical material plasticizing and enlivening the theoretical presentation and bringing it closer to the contemporary social life, and c) the practical message of a sensitive researcher concerned about the fate of society in the most sensitive dimension, meaning axio-normative. It is a book that will become obligatory reading for those professionally involved in the sociology of morality, for students who want to understand social mechanisms (including the functioning of modern society), and anyone interested in the key dimension of collective life.

In the publication under discussion, Janusz Mariański, applying the highest knowledge and professionalism, solves many theoretical issues concerning the sociology of morality as a scientific discipline. He also raises key moral issues in the dimension of social practice. However, he also poses a whole range of questions that still require answers, especially those relating to the functioning of society in the future, for example: Are we slowly entering a post-deontic world, a world without any universal values and norms? Will the spreading permissiveness, and even moral relativism, not reduce our chances of thinking in terms of cultural universalism? Will it be possible to save the basic moral order, one based on values common to all people, requiring minimum respect for other people and respect for their freedoms and other rights? What do people's eternal strivings for truth, goodness, and beauty mean under conditions of full ambivalence and relativism? How are we to rebuild public and personal morality?

The mentioned questions and those not mentioned in this brief overview prove that the research project called "sociology of morality" is not yet complete. It means that further attempts will be made to clarify the issues that pertain to it. Moreover, in these attempts, one may be convinced that the author of the book Sociology and Morality. What Is the Sociology of Morality and Where Is it Heading? will also take part in them. Thus, we are eagerly awaiting more valuable publications by this outstanding moral sociologist. 